CLINICAL ETHICS

\title{
Willingness to donate: an interview study before liver transplantation
}

\author{
M Walter, C Papachristou, G Danzer, B F Klapp, J Frommer
}

J Med Ethics 2004;30:544-550. doi: 10.1136/jme.2003.004879

See end of article for authors' affiliations

....................

Correspondence to: Dr M Walter, Department of Psychiatry, University of Basel, Wilhelm KleinStrasse 27, CH- 4025 Basel, Switzerland; marc. walter@pukbasel.ch

Received 19 May 2003 In revised form 30 June 2003 Accepted for publication 7 August 2003

\begin{abstract}
Objectives: The introduction of the living donation in organ transplantation introduces important new psychological conflicts and ethical questions in the transplantation process. Operation related risks, as well as dependencies in the family structure, generate considerable pressure on potential donors. The aim of the study was to reconstruct the determinants of willingness to donate before transplantation.

Methods: Evaluation of 20 taped and transcribed interviews oriented to current approaches in qualitative interview research. The approach used is based on grounded theory, qualitative content analysis, and the concept of the ideal type.

Results: Before surgery, "openly motivated" donors push for an operation, leaving no room for ambivalence in the evaluation process. They idealise the relationship with the recipient, and link their donation with the individual-partly in subconscious expectations and wishes. In contrast, "openly ambivalent" donors formulate their anxieties and express arguments against donation.

Conclusions: Statements that claim ambivalence towards donation or utterance of arguments against donation indicate earlier coercion. Before transplantation, potential donors should have the opportunity to discuss their emotional situation to help their decision making process.
\end{abstract}

I $\mathrm{n}$ recent years, technical and operative advances in the field of transplantation surgery have led to a continuous rise in the number of people seeking transplantation, increasing the waiting lists of potential organ recipients in contrast to stagnant figures for transplantations actually performed. Furthermore, fewer dying people agreed to donate an organ. ${ }^{1}$ This situation has led to increased mortality among potential recipients on waiting lists. ${ }^{2}$

One possibility to lower the mortality of patients with chronic liver diseases on waiting lists is currently seen in living donor liver transplantation (LDLT). Some initial outcomes of LDLT indicate that resection and transplantation of the right hepatic lobe may provide sufficient liver mass for most organ recipients. ${ }^{3}$ In the postoperative phase, living donors are susceptible to complications such as abdominal abscesses or wound infection ${ }^{4}$; the mortality rate ranges between $0.2 \%$ and $0.8 \% .^{5}{ }^{6}$ In contrast to kidney transplantation, LDLT involves injury of a healthy, non-paired organ, and-owing to a lack of sufficient experience-it is difficult to come up with precise estimates of possible complications for donors. Little research has been done so far on the psychosocial implications of LDLT. Before surgery most potential donors seemed to be highly motivated for donation. ${ }^{7}$ However some potential donors showed impressively high values for anxious depression and pessimism. ${ }^{8}$

A consensus group conference on living donor liver donation distinguished freedom from coercion as the condition on which a decision to donate must be decided. ${ }^{9}$ The efforts made by the consensus group constitute an attempt to define legal rules aimed towards the decision process and the complex medical, ethical, and social situations faced by potential donors. In terms of professional medical competence, these rules entail a binding obligation to use the phase of donor evaluation to seek and to identify both somatic risks and psychosocial risks, as well as to develop therapeutic strategies suited to minimise these risks. Most donors are family members under with considerable pressure to donate in the face of the possibility of helping another family member in a life threatening situation; these potential donors may feel bound by norms and values as well as by personal ties and dependencies to consent to donate. ${ }^{10}$

In spite of these considerations, we are interested in the factors that influence the willingness of potential living donors. Our assumption is that willingness to donate is governed not only by cognition, but also by emotions and interpersonal relationships. In regard to the paradigm of subjective theories of illness, ${ }^{11}$ we speak here of subjective theories of living donors.

Additionally we are also interested in whether emotions, seen in terms of functional or dysfunctional coping strategies, ${ }^{12}$ are systematically repressed, or denied.

\section{PATIENTS AND METHODS \\ Patients}

Between August 2000 and July 2001, 20 potential living donors were evaluated for liver transplantation at the psychosomatics unit of the Berlin Charité Hospital's Medical Clinic. On the basis of a clinical interview, the potential donors were assessed for motivation, ambivalence, and anxiety. From the psychosomatic perspective, the potential donors were found to be suited or were rated as unsuited. The tapes of the clinical interviews were recorded and filed, with the knowledge and informed consent of the potential donors. Sufficient knowledge of the German language was one of the conditions required for participation. The potential donors, 10 women and 10 men, had an average age of 43 years (range 23-68 years). The interviews took between 10-82 minutes, average duration was 32 minutes. The text used for the study included 111937 words (321 narrow spaced pages of transcribed material). Based on the interviews, 17 donors were recommended for donation and three were excluded. In one case, two potential donors were evaluated for one recipient. Neither of them was recommended for donation. Table 1 sums up the sociodemographic parameters as well as recipient diseases. Once the evaluation was complete, a hepatic lobe of each of 12 donors was

Abbreviation: LDLT, living donor liver transplantation. 
resected, in 11 cases the right lobe, in one the left lateral segment. Of the five potential donors who were recommended but not included, four were excluded for medical reasons (fatty liver, vascular status). During the evaluation, one recipient died of multiple haemorrhages in a state of hepatic coma.

\section{Methods}

Realisation and recording of the interviews

The semistructured interviews were conducted by two medical doctors and one psychologist specially trained in transplantation medicine and then recorded on audio tapes. The interview guideline was geared to the following themes: decision making process to donate, fears and anxiety toward surgery, relationship with the recipient, biographical data, previous alcohol and substance use, and information about the present social situation.

The interviews were transcribed in accordance with the rules of the Ulm Textbank. ${ }^{13}$ The interviews were initially evaluated case by case using qualitative content analysis methods ${ }^{14}$ and then analysed comparatively with the aim of generating ideal typical models. ${ }^{15}$

The task of capturing the masked values, interpretation contexts, motives, and affects at the centre of our interest calls for analysis of naturalistic data material in terms of the situations actually involved in the conditions under which precarious decisions are made. The evaluation of the interview data collected was primarily aimed at identifying not quantifiable aspects of communication behaviour, but of subjectively meaningful sense contents. At present there are no detailed, empirically supported hypotheses available-to say nothing of standardised survey instruments-and for this reason we decided to use inductive evaluation strategies, including methods used in the field of qualitative social research. To validate the quality of our results, we worked the evaluations out in structured group discussions. The presentation of our results is oriented to Elliott, Fischer, and Rennie. ${ }^{16}$

The material was structured, first deductively, with the interview guide being used as a point starting to develop evaluation categories, and secondly, by means of so called emerging categories, which are obtained inductively with the aid of iteration. ${ }^{17}$ This method rules out any a priori stipulation of the correct number of categories and the degree of abstraction of category definitions. Instead, the method can be described as a problem to be solved specifically for every object involved. The system of categories is shown in the box.

The interviews were compared on the basis of comparative tables oriented to the single case evaluation framework. ${ }^{18}$ For each dimension of the evaluation framework, we prepared a

\begin{tabular}{|c|c|c|c|c|c|c|c|}
\hline $\begin{array}{l}\text { Donor } \\
\text { number }\end{array}$ & Sex & $\begin{array}{l}\text { Age } \\
\text { (years) }\end{array}$ & Family situation & $\begin{array}{l}\text { Schooling and } \\
\text { training levels }\end{array}$ & $\begin{array}{l}\text { Employment } \\
\text { situation }\end{array}$ & Donor is & Recipient disease \\
\hline 1 & $F$ & 57 & $\begin{array}{l}\text { Divorced, living } \\
\text { with new partner }\end{array}$ & $\begin{array}{l}\text { Intermediate school; } \\
\text { apprenticeship }\end{array}$ & Employed & Partner & $\begin{array}{l}\text { HCC/alcoholic } \\
\text { cirrhosis }\end{array}$ \\
\hline 2 & $\mathrm{~F}$ & 62 & $\begin{array}{l}\text { Married, living } \\
\text { together }\end{array}$ & $\begin{array}{l}\text { Lower secondary } \\
\text { school; } \\
\text { apprenticeship }\end{array}$ & Employed & Spouse & $\begin{array}{l}\text { HCC/alcoholic } \\
\text { cirrhosis }\end{array}$ \\
\hline 3 & M & 34 & $\begin{array}{l}\text { Unmarried, living } \\
\text { without partner }\end{array}$ & $\begin{array}{l}\text { Abitur; university } \\
\text { degree }\end{array}$ & Employed & Son & HCCHCV cirrhosis \\
\hline 4 & $\mathrm{~F}$ & 52 & $\begin{array}{l}\text { Married, living } \\
\text { together }\end{array}$ & $\begin{array}{l}\text { Intermediate school; } \\
\text { apprenticeship }\end{array}$ & Unemployed & Grandmother & Gall duct atresia \\
\hline 5 & $\mathrm{~F}$ & 55 & $\begin{array}{l}\text { Married, living } \\
\text { together }\end{array}$ & $\begin{array}{l}\text { Lower secondary } \\
\text { school; } \\
\text { apprenticeship }\end{array}$ & Unemployed & Spouse & Alcoholic cirrhosis \\
\hline 6 & $\mathrm{~F}$ & 32 & $\begin{array}{l}\text { Unmarried, living } \\
\text { with partner }\end{array}$ & $\begin{array}{l}\text { Abitur; university } \\
\text { degree }\end{array}$ & Unemployed & Daughter & HCV cirrhosis \\
\hline 7 & $\mathrm{~F}$ & 59 & $\begin{array}{l}\text { Married, living } \\
\text { together }\end{array}$ & $\begin{array}{l}\text { Intermediate school; } \\
\text { apprenticeship }\end{array}$ & Employed & Spouse & $\mathrm{HCC} / \mathrm{HBV}$ cirrhosis \\
\hline 8 & M & 29 & $\begin{array}{l}\text { Unmarried, living } \\
\text { with partner }\end{array}$ & $\begin{array}{l}\text { Abitur; university } \\
\text { degree }\end{array}$ & Employed & Son & Alcoholic cirrhosis \\
\hline 9 & $\mathrm{~F}$ & 29 & $\begin{array}{l}\text { Married, living } \\
\text { together }\end{array}$ & $\begin{array}{l}\text { Intermediate school; } \\
\text { apprenticeship }\end{array}$ & Unemployed & Daughter & Alcoholic cirrhosis \\
\hline 10 & M & 30 & $\begin{array}{l}\text { Unmarried, living } \\
\text { without partner }\end{array}$ & $\begin{array}{l}\text { Abitur; university } \\
\text { degree }\end{array}$ & Employed & Son & $\mathrm{HCC}$ \\
\hline 11 & M & 51 & $\begin{array}{l}\text { Married, living } \\
\text { together }\end{array}$ & $\begin{array}{l}\text { No schooling } \\
\text { completed; no } \\
\text { apprenticeship }\end{array}$ & Unemployed & Father & $\begin{array}{l}\text { Autoimmune } \\
\text { hepatitis }\end{array}$ \\
\hline 12 & M & 52 & $\begin{array}{l}\text { Married, living } \\
\text { together }\end{array}$ & $\begin{array}{l}\text { Abitur; university } \\
\text { degree }\end{array}$ & Employed & Father & PSC \\
\hline 13 & M & 68 & $\begin{array}{l}\text { Married, living } \\
\text { together }\end{array}$ & $\begin{array}{l}\text { Abitur; university } \\
\text { degree }\end{array}$ & Retired & Spouse & $\mathrm{HCC} / \mathrm{HBV}$ cirrhosis \\
\hline 14 & $\mathrm{~F}$ & 47 & $\begin{array}{l}\text { Married, living } \\
\text { together }\end{array}$ & $\begin{array}{l}\text { Abitur; university } \\
\text { degree }\end{array}$ & Employed & Spouse & HCV cirrhosis \\
\hline 15 & M & 23 & $\begin{array}{l}\text { Unmarried, living } \\
\text { with partner }\end{array}$ & $\begin{array}{l}\text { Intermediate school; } \\
\text { apprenticeship }\end{array}$ & Unemployed & Son & $\begin{array}{l}\text { HCC/alcoholic } \\
\text { cirrhosis }\end{array}$ \\
\hline 16 & M & 48 & $\begin{array}{l}\text { Married, living } \\
\text { together }\end{array}$ & $\begin{array}{l}\text { Intermediate school; } \\
\text { no diploma }\end{array}$ & Employed & Brother & HCV cirrhosis \\
\hline 17 & $\mathrm{~F}$ & 26 & $\begin{array}{l}\text { Unmarried, living } \\
\text { with partner }\end{array}$ & $\begin{array}{l}\text { Intermediate school; } \\
\text { apprenticeship }\end{array}$ & Employed & Daughter & $\begin{array}{l}\text { HCC/alcoholic } \\
\text { cirrhosis }\end{array}$ \\
\hline 18 & M & 27 & $\begin{array}{l}\text { Unmarried, without, } \\
\text { a steady partner }\end{array}$ & $\begin{array}{l}\text { tAbitur; university } \\
\text { degree }\end{array}$ & Employed & Father & Hepatoblastoma \\
\hline 19 & $\mathrm{~F}$ & 46 & $\begin{array}{l}\text { Married, living } \\
\text { together }\end{array}$ & $\begin{array}{l}\text { Lower secondary } \\
\text { school; } \\
\text { apprenticeship }\end{array}$ & Employed & Mother & $\begin{array}{l}\text { Budd-Chiari } \\
\text { syndrome }\end{array}$ \\
\hline 20 & M & 27 & $\begin{array}{l}\text { Unmarried, living } \\
\text { with partner }\end{array}$ & $\begin{array}{l}\text { Abitur; university } \\
\text { degree }\end{array}$ & Employed & Son & Alcoholic cirrhosis \\
\hline
\end{tabular}




\section{Interview category system}

Dimension: donor

- Biography (childhood, parents, siblings, vocational development)

- Present life situation (employment situation, family situation)

- Characterisation of personality (utterances on self image, own emotions, and feelings)

- Own illnesses (previous illnesses, present state of health, medical drugs, alcohol consumption)

Dimension: recipient

- Biography (childhood, parents, siblings, vocational development) and present life situation

- Characterisation of personality

- Recipient disease (genesis and development of liver disease, alcohol problems)

Dimension: transplantation

- Relationship to recipient (emotional utterances on quality of relationship, development of relationship)

- Willingness to donate (emotional utterances on willingness to donate, course over time, development of willingness to donate, anxieties and fears regarding operation, possible reaction in case of transplant rejection, possible reaction in case of medical counterindication for donation, reasons given for willingness to donate)

- Physician behaviour (critical assessment, praise, and recognition of physician behaviour)

- Utterances on the future (future perspective, emotional utterances on time after operation)

table containing the comments of all 20 donors interviewed, condensed with the aid of qualitative content analysis. This was followed by a comparison of the comments of all subjects at one point of the interview, firstly concentrating on interindividual similarities and contrasts. ${ }^{17}$ This involved taking into consideration correspondences observed for at least two people. The final step involved comparing the entries in all comparative tables, the aim being to work out a typology of a supraindividual personality characterisation as well as differentiations of the types obtained

\section{RESULTS}

\section{Case comparation}

\section{Recipient diseases}

Seventeen donors rated the recipient's disease as very severe: "Her belly started to swell out again, and she lost more and more weight, and for me it was really frightening, the way she was wasting away" (donor number 6). As shown in table 1, a total of nine recipients were set to receive transplant due to alcoholic cirrhosis. Asked about this, all of the potential donors conceded that alcohol abuse was a causative factor, though they also mentioned some other possible causes: "a big fat medical book that says that the reason for it is alcohol. And what else, I don't know if there can be other reasons for it, I don't know" (donor 2). Some also added other explanations and reservations or admitted being in part responsible for the recipient's alcohol consumption: "People drink everywhere, we even notice that ourselves, where we're never without-well, we just drifted into it, unconsciously" (donor 5). Four donors emphasised that the recipient was not an alcoholic or regular heavy drinker but instead "someone who just drank a beer after work" (donor 8). In contrast to some other recipient diseases, the donor for alcoholic cirrhosis patients described interpersonal conflicts between donor and recipient; three donors criticised recipients for dealing too passively with their disease and for not seeking medical attention early enough (donors 2, 5, and 14). One donor (female) further criticised the recipient (male) for concealing from her that he had been told to avoid drinking alcohol (donor 2), and another donor reported that the recipient had repeatedly begun drinking again (donor 5). However, all donors emphasised that the recipients had not consumed any alcohol since diagnosis.

\section{Donor-recipient relationship}

Twelve donors rated their relationship with the recipient as "very good", "very close", or "very stable" (table 2); four of these recipients were suffering from alcoholic cirrhosis. In describing their relationships, the subjects tended to use markedly idealising terms like: "I have a fabulous relationship to her" (donor 6); critical utterances were expressed only indirectly: "People quarrel, every family has quarrels, but over little things, it's really a super relationship, really!" (donor 10). Two sons described their very close ties to their mother: "I still live with my parents at home, and that's why our relationship is very close. In our family the mother-son relationship is more pronounced than the mother-daughter relationship" (donor 3). In cases in which donors were to donate hepatic lobe to their partner, emphasis was often placed on the shared years of the relationship: "We've now been married for 35 years: Basically, our marriage has been very good" (donor 7). One donor (female) reported that her contact with her father had taken a turn for the better since her decision to donate: "The relationship is now beginning to become a real father-daughter relationship again. You know, he's affectionate, I feel he likes having me now around him" (donor 9). She reported perceiving entirely new traits of her father now that he had stopped drinking: "The sudden rages are gone, because alcohol always played a role in them" (donor 9).

A total of five donors described their relationship with the recipient as "not good" or "not close" (table 3). Whereas one donor (female) put it in clear terms: "Well, I've never really had a good relationship to my mother" (donor 17), three others justified their assessments with reference to their spatial distance from the recipient: "Because, as I said, I am simply too far away from it all" (donor 16). Four donors expressed themselves critically on their potential recipients, who were suffering from alcoholic cirrhosis. These remarks were concerned exclusively with communication problems with the recipient: "He can't talk things over, that bothers me very much in our relationship, the fact that you can't talk any problems over with him" (donor 1); "I don't know how to see my mother, because I can never tell if she's telling the truth or lying" (donor 17). These conflicts were common in donors who were willing to donate the liver lobe for a recipient with alcoholic cirrhosis.

Responding to a direct interview question, 18 potential donors saw no chance that their donation might alter their relationship. But looking at future donor prospects, we observed certain expectations, hopes, and wishes. If donors expressed no wish for change following donation, they did express the hope that their relationship would remain as good as it presently was. In 13 cases, we found expectations or wishes for the future (for the time following donation) although these wishes were as a rule not openly expressed: "Say, we can't handle that now, once we've both been 


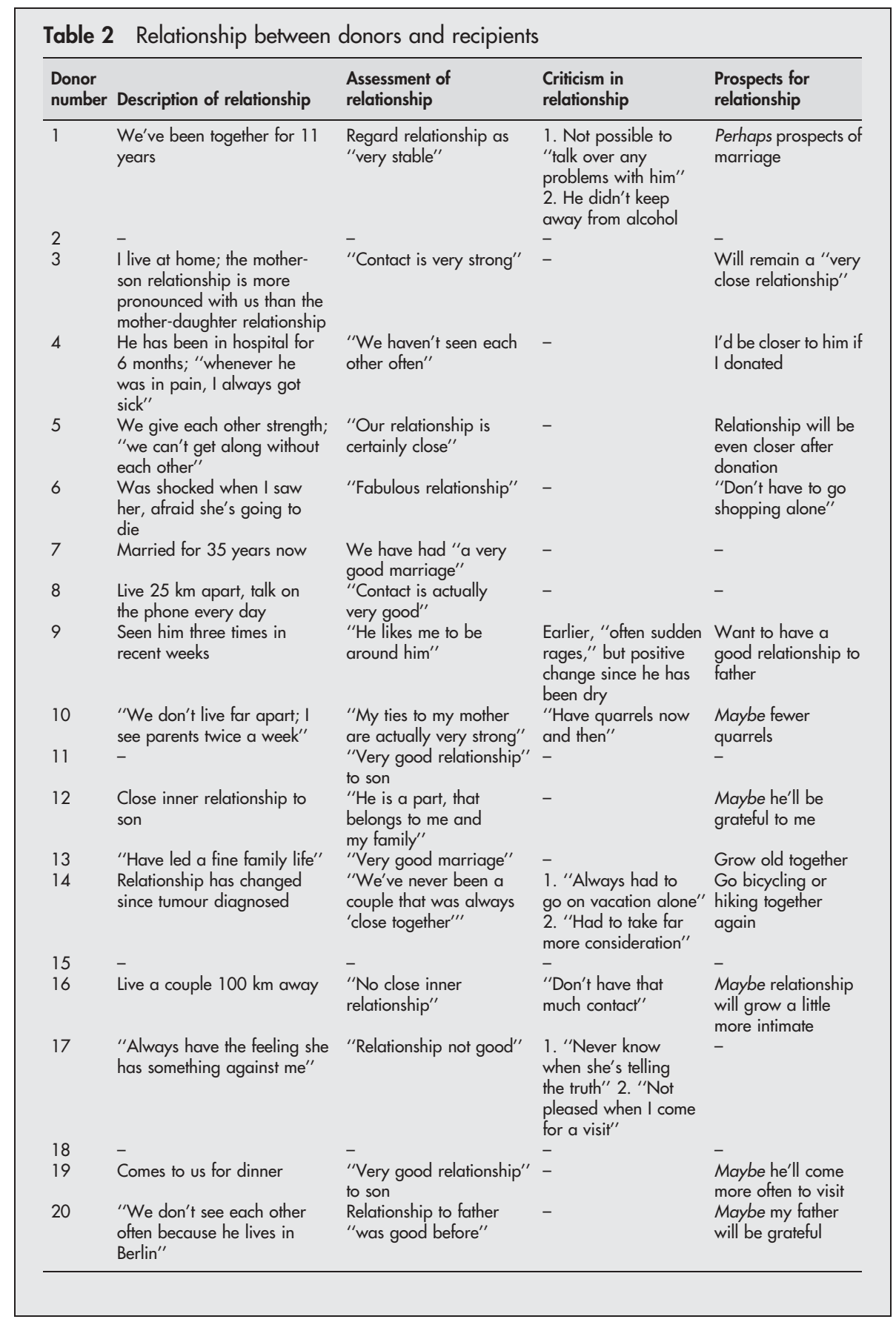

operated on, because the problem now is the small garden allotments. You can't have two gardens. I'm completely on his side, but I don't absolutely have to be married to him" (donor 1). The donor was reporting on her plans to share a garden with the recipient after donation and subsequently addressed the question of marriage. A wish, closely bound up with the donor's relationship with her mother, is also expressed symbolically in the following comment: "Well, I just don't know how the relationship is supposed to change. I can continue going shopping with my mother (laughs), I won't have to go alone (laughs), well, we'll take turns, andthe family chauffeur-before I go shopping alone, I'd rather have my mother along" (donor 6). Expectations and wishes are not openly admitted, and once mentioned, they are quickly played down again: "And my father will probably be grateful, but it's not that I wish it, I don't specifically wish that" (donor 20).

\section{Willingness to donate}

During the interviews, 16 donors indicated their firm determination to donate. In the interviews, only four donors expressed doubts, clearly stating that they had not yet come to a decision. In the course of the interview, one donor questioned his commitment to donate, pointing to the psychological stress with which he was faced in connection with the decision process: “... because it's taking so long, and my nerves have already suffered quite a bit from the whole situation, and I'm pretty troubled about what I should do, what's right and what's not (weeps)" (donor 4). Two other donors indicated that they had not yet reached a decision (donors 14 and 17), and one donor (female) doubted the possible benefits of the operation as the recipient might die from surgery, whereas he might live on for a while without the new organ (donor 2). One striking aspect of the interviews is that donors rarely-and at best cautiously, 
tentatively, unclearly, and cryptically-expressed reservations and doubts on their own possible donation: "My decision is firm, as firm as the Leaning Tower of Pisa" (donor 5).

The most frequent reason indicated for the decision to donate was the feeling of inescapable necessity (13). Other reasons were generally bound up with the thematic areas of help (2), love (2), and fear of loss (2). Two donors mentioned feelings of duty as their reason for wanting to donate (donors 4 and 15). Most donors responded in brief sentences, for the most part citing altruistic motivations, without going any further into their own personal motives. Only the four ambivalent potential donors advanced reasons against donation: the operation entailed a high risk for the recipient (1); fear of surgery (2); work disablement after surgery (1); a poor relationship with the recipient (1).

Half of our potential donors explicitly denied having any fear of the operation. Two donors cautiously indicated that a number of uncertainties and/or physical complaints might well be in store for them: "You probably always have stomach pressure, a certain nervousness, that's no-nothing normal, sure; so I can't say I'd be as well off as I would if I-I don't know-did something — sure, that would be dishonest; but I'm not afraid or in panic; but there's sure to be some stomach pressure" (donor 10). Utterances causing doubt on consent to donate are marked by unclear, hinting verbalisations characterised by word omissions and incomplete sentence structures. Six other donors admitted mild fears, while only two donors indicated having major fears over the operation. Both of these donors proved to be ambivalent towards their willingness to donate.

Table 3 presents the ambivalent donors. It turned out that donor psychosocial criteria such as unemployment and psychosocial conflicts were not closely related to ambivalence and anxiety before surgery. Two of four ambivalent donors reported that their present life situation was satisfactory. Three of them were prepared to undergo surgery for a recipient with alcoholic cirrhosis. However, quality of relationship does appear to be a decisive criterion for willingness to donate. A donor-recipient relationship experienced as good is associated in all cases with a large measure of motivation to donate. The ambivalent donors, on the other hand, either had nothing to say or perceived their relationship with the recipient in a negative way.

\section{Type differentiation}

On the ideal-typical level, it is possible to work out two contrasting variants of donor willingness to donate: the "openly motivated" donor and the "openly ambivalent" donor. The "openly motivated" donor wants absolutely to donate, and to do so as quickly as possible; in the interviews he or she cites only reasons in favour of donation; none against it. These donors rate the risk posed by the operation as extremely low, denying any anxiety. It is only in hints and intimations that "openly motivated" donors articulate their avoidance strategies: the interview tends to be short (at most 10 minutes), is often marked by omissions and changes of subject. By comparison, the "openly ambivalent" donor tends to waver, to specify "moral obligation" as her reason to donate, and to indicate that she has a great deal of anxiety about the operation. In the interview, she tends to seek to break out of the stressful situation caused by the inability to decide about the donation.

The key influencing variable for willingness to donate turns out to be the quality of the donor-recipient relationship: the "openly motivated" donor seems to idealise his relationship with the recipient, linking his willingness to donate with his own expectations and wishes for the relationship in the period following surgery, and expressing this only indirectly and symbolically in the interview. Relationship conflicts are mostly denied. The "openly ambivalent" donor, on the other hand, tends more to view her relationship with the recipient in a critical view, seeing no potential for improvement of the relationship. We can note for both types that in cases of possible donation for a person suffering from alcoholic cirrhosis, donors describe interpersonal conflicts. The reasons indicated are mainly bound up with the harmful impact of alcohol on the recipient's personality. The "openly motivated" donor hopes for a cure for the recipient's underlying disease, that the operation will lead to a protracted period of recipient abstinence from alcohol, and that thus, in the end, the recipient will change his personality and improve the quality of his relationship with the donor. The "openly ambivalent" donor, on the other hand, sees in their donation no hope for herself or for the relationship, justifies her uncertainty regarding willingness to donate by advancing arguments against donation and describing her own anxiety influencing the outcome of the operation.

\begin{tabular}{|c|c|c|c|c|c|}
\hline $\begin{array}{l}\text { Donor } \\
\text { number }\end{array}$ & Decision & $\begin{array}{l}\text { Verbalised } \\
\text { anxieties }\end{array}$ & $\begin{array}{l}\text { Present } \\
\text { situation }\end{array}$ & $\begin{array}{l}\text { Recipient } \\
\text { disease }\end{array}$ & $\begin{array}{l}\text { Relationship with } \\
\text { recipient }\end{array}$ \\
\hline 2 & $\begin{array}{l}\text { Doubts, "because } \\
\text { recipient might die } \\
\text { during the operation" }\end{array}$ & - & $\begin{array}{l}\text { "Like to work"; } \\
\text { "next year time } \\
\text { for retirement" }\end{array}$ & $\begin{array}{l}\text { Alcoholic } \\
\text { cirrhosis }\end{array}$ & - \\
\hline 4 & $\begin{array}{l}\text { "Decision taking a } \\
\text { long time, nerves } \\
\text { have suffered" }\end{array}$ & $\begin{array}{l}\text { "Am very afraid; } \\
\text { I'm unsettled } \\
\text { because I don't } \\
\text { know how things } \\
\text { are going } \\
\text { to go" }\end{array}$ & $\begin{array}{l}\text { Unemployed; } \\
\text { "all year the } \\
\text { situation was } \\
\text { very tense" }\end{array}$ & $\begin{array}{l}\text { Gall duct } \\
\text { atresia }\end{array}$ & $\begin{array}{l}\text { "Whenever he } \\
\text { was in pain, I } \\
\text { always got sick"; } \\
\text { "we have not seen } \\
\text { each other offen" }\end{array}$ \\
\hline 15 & $\begin{array}{l}\text { "Agreed right away, } \\
\text { didn't hesitate a } \\
\text { minute"; "but there } \\
\text { are also reasons not } \\
\text { to go through with it" }\end{array}$ & $\begin{array}{l}\text { Not able to liff } \\
\text { heavy things for } \\
\text { six months after } \\
\text { operation; may } \\
\text { not find a job }\end{array}$ & $\begin{array}{l}\text { Trained as a } \\
\text { mechanic, } \\
\text { presently } \\
\text { unemployed; } \\
\text { "am often at my } \\
\text { parents place" }\end{array}$ & $\begin{array}{l}\text { Alcoholic } \\
\text { cirrhosis }\end{array}$ & - \\
\hline 17 & "My decision is open" & $\begin{array}{l}\text { "Am afraid; I } \\
\text { don't know what } \\
\text { may happen } \\
\text { during the } \\
\text { operation" }\end{array}$ & $\begin{array}{l}\text { Employed with } \\
\text { an insurance } \\
\text { company; "living } \\
\text { in a happy } \\
\text { relationship" }\end{array}$ & $\begin{array}{l}\text { Alcoholic } \\
\text { cirrhosis }\end{array}$ & $\begin{array}{l}\text { "Relationship not } \\
\text { good"; "always } \\
\text { have the feeling } \\
\text { she has something } \\
\text { against me" }\end{array}$ \\
\hline
\end{tabular}




\section{DISCUSSION}

In our study we found, empirically, two contrasting extreme types of donors: The "openly ambivalent" and "openly motivated" type. We found no mixed types. The ratio of 16 "openly motivated" donors to four "openly ambivalent" donors, as well as the lack of any donor attempts to balance the pros against the cons in the evaluation interviews, indicate to us that the given situation constituted a high threshold to donor expression of fears and misgivings. In most cases, the "openly motivated" donors pushed for an operation. This finding is supported by the limited number of studies that have been published in the field. ${ }^{19}{ }^{20}$ In this study, the donors cite altruistic reasons for their decision, denying or playing over their anxieties about possible surgery. Our results indicate that the marked ambivalence shown by individual subjects is mainly connected with fears about the operation, the risks of which can, at present, not be predicted with any degree of objective certainty. ${ }^{21}$

High motivation for living donation is influenced in particular by the donor's relationship with the potential recipient. Whereas the "openly ambivalent" donors as a rule view the donor-recipient relationship critically, the "openly motivated" donors show an impressive tendency to idealise the relationship. Here, certain expectations and wishes that were expressed only indirectly in the interview are linked to the manner in which the relationship might be (re)formulated following surgery. Expectations extended to a wish to alter the recipient's character and to embark on a new, harmonious relationship. Denial of anxieties, idealisation of the donor-recipient relationship, and expectations and wishes point toward an adaptive coping strategy on the part of potential donors following confrontation with a stressor or a trauma ${ }^{22}$ as the question for donation may be seen. In earlier stages of the attempt to cope with the trauma, denial and intrusion tend more to exclude one another, which, in unfavourable cases, can lead those concerned to cling to one of the two extreme positions or may give rise to an unmediated oscillation between avoidance and intrusion. ${ }^{23}$

These theoretical reflections permit us to assume that in this situation-marked as it is by high levels of normativemoral, family related, and institutional pressure-potential donors deny negative intrusions in connection with the threat to their physical integrity. They also indicate that these donors may at the same time idealise both the recipient and the shared relationship, linking their own "egoistic" expectations to the altruistic act of donation as a means of protecting the self. Interestingly, even though they reported on numerous interpersonal conflicts with the potential recipient, the donors for patients with alcoholic cirrhosis turned out to be no less "openly motivated" than other donors.

Like the recipients with alcoholic cirrhosis, these donors tend largely to play down the recipient's alcohol consumption, ${ }^{24}$ a coping mechanism that is understandable in connection with the manner in which they idealise their relationship with the recipient.

Understood in this way, the aim of therapeutic intervention is to foster adaptive coping processes by working through the trauma together with the subject. What this means for practical clinical-psychosomatic evaluations of donors is that it is important to provide the donor opportunity to unfold and report as openly as possible his misgivings and anxieties. ${ }^{25}$ This requires the interviewer to go beyond her own preferences as well as the institutional constraints to which she is subject and to examine her activity in a process of reflection. The interviewer must clearly understand that she is imposing psychological pressure upon the potential donor, possibly not allowing the donor to refuse to donate, if she seeks-and be it unconsciously-to force the donor's motivation to donate against the latter's doubts or misgivings. Potential donors who express few misgivings in the interview, veiling their ambivalence, should for this reason be given special consideration. In our view, both utterances that seem to indicate doubts as to the decision to donate and reasons advanced against donation, cast doubt on the voluntary nature of the decision.

In the communication process the potential donor should perceive that he has a choice of two alternative decisions. In the shared model of decision making, interviewer and potential donor work towards reaching an agreement. Both parties make an investment in the ultimate decision making. ${ }^{26}$ Generally, patients may vary in their desire for sharing in the decision making part, but most patients prefer a listening doctor who is open to the ideas of patients ${ }^{27}$ and also to their doubts concerning the treatment. Several communication skills for the interview with patients are well described. ${ }^{28}$ The doctors and psychologists who are involved in the preoperative evaluation process with living donors should use some specially trained communication skills in the preoperative interview. They should not only use empathy to show that they have some sense of how the donor is feeling, but they should also check if the donor needs help with decision making, especially when the psychological pressure is high; they then need a lot of time for the communication and decision process. Finally they should accept the decision, even when the potential donor does not want to donate.

Looking at it from a scientific perspective, it is absolutely essential to follow on with the development and further differentiation of research on the process of decision making by living donors. This applies not only to the effects that the disease has on the donor's decision to donate, the nature of the relationship between donor and recipient, and other influencing factors that play a role during the evaluation process; it also concerns psychosocial and ethical factors that become manifest only in the period following donation.

\section{Authors' affiliations}

M Walter, C Papachristou, G Danzer, B F Klapp, Clinic for Internal Medicine and Psychosomatics, Charité, Humboldt-University Berlin, Berlin, Germany

M Walter, Department of Psychiatry, University of Basel, Basel, Switzerland

J Frommer, Department of Psychosomatic Medicine and Psychotherapy, Otto-von-Guericke-University Hospital, Magdeburg, Germany

\section{REFERENCES}

1 Kerridge IH, Saul P, Lowe $M$, et al. Death, dying and donation: organ transplantation and the diagnosis of death. J Med Ethics 2002;28:89-94.

2 Marcos A. Right lobe donor liver transplantation: A review. Liver Transplant 2000:6:3-20.

3 Marcos A, Fisher RA, Ham JM, et al. Selection and outcome of living donors for adult to adult right lobe transplantation. Transplantation 2000;69:2410-15.

4 Ohkohchi N, Katoh H, Orii T, et al. Complications and treatments of donors and recipients in living-related liver transplantation. Transplant Proc 1998;30:3218-20.

5 Renz JF, Roberts JP. Long-term complications of living donor liver transplantation. Liver Transplant 2000;6:S73-S76.

6 Broelsch CE, Malagó M, Testa G, et al. Living donor liver transplantation in adults: Outcome in Europe. Liver Transplant 2000;6:S64-S65.

7 Goldman LS. Liver transplantation using living donors. Preliminary donor psychiatric outcomes. Psychosomatics 1993;3:235-40.

8 Walter M, Bronner E, Steinmüller T, et al. Psychosocial data of living donors before living donor liver transplantation. Clin Transplant 2002; 16:55-60.

9 Liver Organ Donor Consensus Group. Consensus statement on the live organ donor. JAMA 2000;284:2919-26.

10 Hodson ME. Transplantation using lung lobes from living donors. J Med Ethics 2000;26:419-21.

11 Danzer G, Rose M, Walter M, et al. The theory of individual health. J Med Ethics 2002;28:17-19.

12 Cohen F, Lazarus RS. Active coping processes, coping disposition, and recovery from surgery. Psychosom Med 1973;35:375-89. 
13 Mergenthaler E, Stinson $\mathrm{CH}$. Psychotherapy transcription standards. Psychother Res 1992;2:125-42.

14 Kracauer S. The challenge of qualitative content analysis. Public Opinion Quarterly 1952;16:631-42.

15 Frommer J, Rennie D, eds. Qualitative psychotherapy research. Methods and methodology. Lengerich: Pabst, 2001.

16 Elliott R, Fischer CT, Rennie DL. Evolving guidelines for the publication of qualitative research in psychology and related fields. Br J Clin Psychol 1999;38:215-29.

17 Strauss AL. Qualitative analysis for social scientists. Cambridge: Cambridge University Press, 1987

18 Jüttemann G. Komparative Kasuistik. Heidelberg: Asanger, 1990.

19 Trotter JF, Wachs M, Trouillot T, et al. Evaluation of 100 patients for living donor liver transplantation. Liver Transplant 2000:6:290-5.

20 Walter M, Bronner E, Pascher A, et al. Psychosocial outcome of living donors after living donor liver transplantation. Clin Transplant 2002;16:339-44.

21 Pascher P, Sauer IM, Walter M, et al. Donor evaluation, donor risk, donor outcome and donor quality of life in adult-to-adult-living donor liver transplantation. Liver Transplant 2002;8:829-37.
22 Lamprecht F, Sack M. Posttraumatic stress disorder revisited. Psychosom Med 2002;64:222-37

23 Horowitz MJ. Psychological responses to serious life events. In: Hamilton V, Warburton DM, eds. Human stress and cognition: An information processing approach. Chichester: Wiley, 1979:235-63.

24 Walter M, Scholler G, Moyzes D, et al. Psychosocial prediction of abstinence from ethanol in alcoholic recipients following liver transplantation. Transplant Proc 2002;34:1239-41.

25 Burroughs TE, Hong BA, Kappel DF, et al. The stability of family decisions to consent or refuse organ donation: would you do it again? Psychosom Med 1998;60:156-62.

26 Charles C, Gafni A, Whelan T. Decision-making in the physican-patient encounter: revisiting the shared treatment decision-making model. Soc Sci Med 1999:49:651-61.

27 McKinstry B. Do patients wish to be involved in decision making in the consultation? A cross sectional survey with video vignettes. BMJ 2000;321:867-71

28 Maguire $\mathbf{P}$, Pitceathly $\mathrm{C}$. Key communication skills and how to acquire them. BMJ 2002;325:697-700.

\section{$\mathrm{ECHO}$}

\section{Halting female genital mutilation in Sudan rests with its leaders}

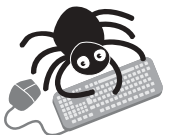

Please visit the Journal of Medical Ethics website [www. imedethics. com] for a link to the full text of this article. u

nvestigators of students' attitudes to female genital mutilation (FGM) in Sudan have urged the government, religious leaders, and teachers to clarify religious and legal attitudes towards the practice. FGM is still condoned on religious or cultural grounds, it seems, even though it has been banned since the mid-1970s.

Their survey showed that more than $90 \%$ of male and female university students knew the risks and complications, yet almost a fifth favoured FGM, were unsure, or did not condemn it. Over half the female respondents were circumcised - at the behest mostly of their mother or grandmother. Two thirds of male students, but only almost half of female students deemed FGM illegal. The law relating to FGM it seems, is open to the interpretation that clitoridectomy is permissible. Between $50 \%$ and $78 \%$ of Muslim students of both sexes considered FGM necessary for religious reasons. The traditional view that FGM increases a woman's chances of marriage was refuted: three quarters of the men said that they preferred to marry an uncircumcised woman, and support from the women was under $10 \%$. Almost $80 \%$ or over thought that FGM should stop. The overall response rate was $83 \%$.

The anonymous questionnaire was handed out to the first 500 students entering the campus of Khartoum University during two weeks in July 2000.

Over $80 \%$ of Sudanese women have undergone FGM according to a study in the mid1990s. The aim of the current study was to assess attitudes to it within a contemporary setting.

A Sexually Transmitted Infections 2003;79:220-223. 